\title{
Antecedents of a Global Mindset: A Mixed Method Analysis of Indian, Chinese and Japanese Managers
}

\author{
Subramaniam Ananthram \\ Curtin University \\ E-Mail: s.ananthram@curtin.edu.au \\ David Pick \\ Curtin University \\ E-Mail: David.Pick@cbs.curtin.edu.au \\ Theodora Issa \\ Curtin University \\ E-Mail: Theodora.Issa@curtin.edu.au
}

\begin{abstract}
There is a growing literature pointing to the importance of global organizations having managers with global mindsets. However, some theoretical issues and contradictory research findings require attention, especially in the case of non-Western contexts. The aim of this article is to examine the extent to which current understandings about the antecedents of global mindsets apply to Indian, Chinese and Japanese organizations. Employing a quantitatively driven mixed method approach, survey data from 504 managers, and interviews with 36 executives and managers is analyzed. The findings suggest convergence in the three Asian contexts that has theoretical and practical implications.
\end{abstract}

Keywords: Global Mindset, India, China, Japan, Mixed Method Approach

\section{INTRODUCTION}

Multinational corporations around the globe are experiencing the profound effects of globalization (Cateora, 1993; Giddens, 2002; Levy, et al. 2007; Parkan, 2009). Rogers and Blonski (2010) contend that forces of globalization enable the integration of multiple geographies, cultures, nationalities, ages and styles in 
organizations around the world, and has an enormous impact on business relationships. The influences of globalization are well summarized by Cohen (2010) as falling into three broad headings: macroeconomic (shifting centers of economic activity to and within Asia); environmental and social (transition to knowledge intensive industries); and, business and industry (the emergence of new business models). However, the nature of globalization itself is also changing. The process of globalization is characterized by its multidimensionality and tensions. Held and McGrew (2007: 3) identify these in terms of 'structural shifts from a world of discrete but inter-dependent nations to the world as a shared social [and economic] space'. As part of these changes, globalization is a major force driving the reconfiguration of organizations that is challenging managers at all levels (Pies, Beckmann \& Hielscher (2010). Over the past two decades, a body of research has suggested that meeting this challenge requires the development of a managerial 'global mindset' (Bartlett \& Ghoshal, 1998, Gupta \& Govindarajan, 2002; Bowen \& Inkpen, 2009; Cohen, 2010).

Three important epicenters of globalization are China, India and Japan. For China, rapid growth has propelled the nation to being the second largest economy in the world, and India is likely to follow a similar path (Das, 2006). By 2050, it is possible that China and India will occupy global economic status approaching that of the currently most influential Western nations (USA and the EU) (Ikenberry, 2008). In contrast to China and India, Japan has experienced stagnation over the past two decades after a long period of growth (Pempel, 2005). Nevertheless, it still enjoys status as a global economic, political, and technological powerhouse that China and India aspire to, at least emulating, if not overtaking. It is clear then that each of these nations is at different stages of development; India as an emerging nation, China an emerging post-socialist nation, and Japan entering a post-development stage (Pekkanen \& Tsai, 2005). This being so, it could be argued that together, these three nations have the potential to be at the core of an evolving 'Asian Century'. As such, it is important to examine the extent to which Western business ideas and consciousness has penetrated the business elites of these nations, and the possible implications (McKenna, 2011).

With this in mind, we aim to better understand the cognitive abilities and orientations towards global engagement of managers in organizations in China, India, and Japan, through the employment of the concept of 'global mindset'. This is a concept that is a fairly recent development, and there is much research to be done to increase understanding about its usefulness and applicability. There is a growing body of research that indicates the importance of the global mindset to the successful 
performance of contemporary organizations (Gupta \& Govindarajan, 2002; Ananthram, Chatterjee \& Pearson, 2010; Cohen, 2010). Global mindsets refer to cognitive, existential and behavioral factors that together create 'a highly complex cognitive structure characterized by an openness to and articulation of multiple cultural and strategic realities on both global and local levels, and the cognitive ability to mediate and integrate across this multiplicity' (Levy et al, 2007, p.27). A more recent attempt to define 'global mindsets' was made by Rogers and Blonski (2010, p. 19), who define 'global mindset' as 'the capacity to engage in a boundaryless and synthesize cognitive process that identifies opportunity and innovation in complexity'. Based on these different contentions, it seems then that understanding the nature and characteristics of the global mindsets that exist amongst managers in different contexts will provide important insights into cross-cultural differences in perspectives and commitments. The aim of this paper is to analyze the antecedents and characteristics of the 'global mindset' that exists among Chinese, Indian and Japanese executives. This will then provide an insight into whether Western business ideas and consciousness are dominant, influential, or that there is a new and developing negotiated perspective in which hybridized perspectives prevail.

\section{THE GLOBAL MINDSET}

The importance of the global mindset arises from the need for skill-sets that will facilitate efficient and effective functioning of organizations in the increasingly complex and dynamic global business environment. This notion is consistent with the change in managerial thought that it is vital to encourage managers to develop skills, competencies, values and a culture conducive to operating successfully in the global economy (Rhinesmith, 1993; Bouquet, 2005; Rogers \& Blonski, 2010). In this context, many studies (Beechler, et al. 1999; Rhinesmith, 1995; Jeanett, 2000; Gupta \& Govinarajan, 2002; Beechler \& Bltazley 2008) have placed emphasis on managerial level reform, namely, the cultivation of a global mindset. Murtha, Lenway and Bagozzi (1998) and Harveston (2000) contend that a critical success factor for any organization is the level of global mindset orientation amongst its managers. These notions provide a rationale for a deeper level understanding of skill-sets associated with the development and cultivation of a global mindset among managers (Rhinesmith, 1992; 1993; 1995; Bartlett \& Ghoshal, 1998; Murtha, Lenway \& Bagozzi 1998; Beechler, et al. 1999; Jeanett, 2000; Gupta \& Govindarajan, 2002; Begley \& Boyd, 2003; Beechler \& Bltazley, 2008).

A number of studies have linked managerial global mindset with certain 
antecedent characteristics (Murtha, Lenway \& Bagozzi 1998; Beechler, et al. 1999; Harveston, 2000; Bouquet, 2005). This study tests six antecedents, namely knowledge and information, skills and abilities, risk tolerance, global identity, boundary spanning activities, and international experience that have been reported in the literature as contributing to the cultivation and development of a managerial global mindset in three Asian countries, India, China, and Japan. An in-depth understanding of these antecedent characteristics and their relationships with managerial global mindset is formulated into an integrated conceptual framework represented in Figure 1. A detailed explanation of the literature surrounding the postulated hypotheses is presented next.

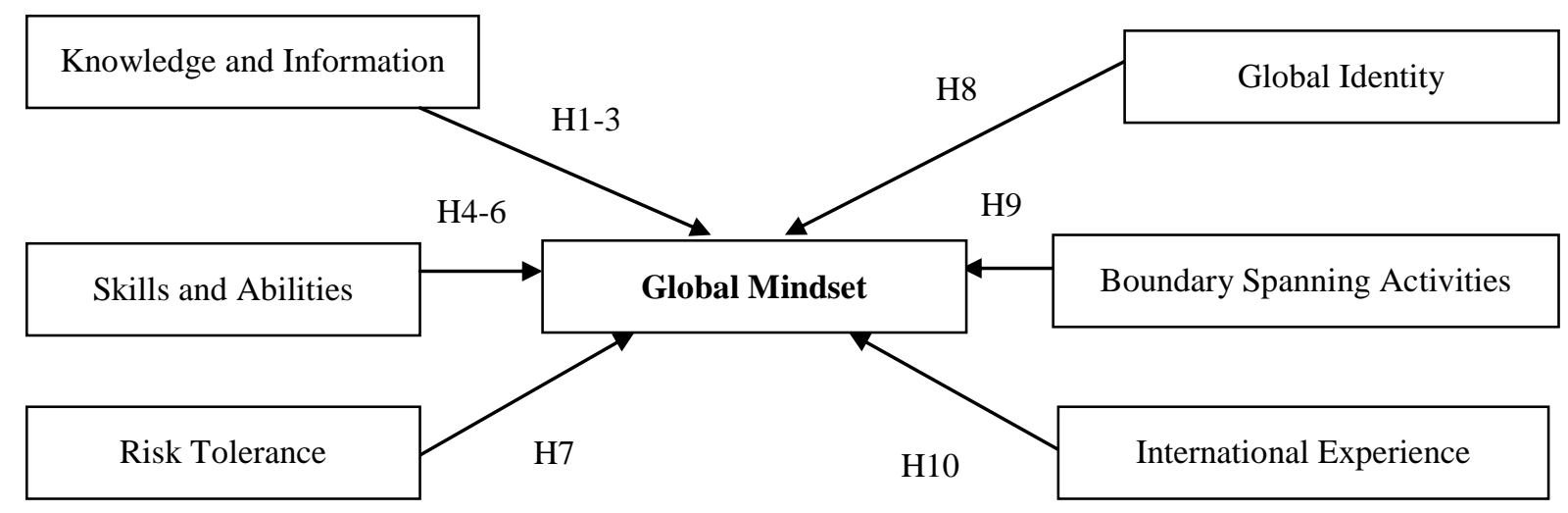

Figure 1 A Conceptual Framework of the Antecedents of a Global Mindset

\section{Knowledge and Information}

Knowledge as an asset, and knowledge management as a process, has gained tremendous importance, particularly in a globally competitive environment (Naik \& Iyengar, 2003). Organizations realize the importance of knowledge, which managers possess, as a valuable resource (Miller \& Wurzburg, 1995; Ortenblad, 2004). The ability of organizations to store and share knowledge through structured processes, often involving technological intervention, is vital to ensure the smooth functioning of operations (Baines, 1998; Gunasekaran et al. 2003). Kedia and Mukherji (1999) have identified three dimensions of knowledge and information. First, they identify that knowledge of socio-political differences across countries and regions (knowledge 1) is vital in order to liaise with managers from different contexts. Indeed, 'multinational companies are particularly vulnerable to multiple political, cultural and economic systems within which they operate' (Fatehi, 1996: 237). The second facet of knowledge, vital from a managerial point of view to enable smooth operation across 
borders, is the knowledge of organizational and societal culture and cross-cultural issues that impact management (knowledge 2). Hofstede (1991) and Bartlett and Ghoshal (1998) support the view that a thorough understanding of the host country organizational and societal culture is of paramount importance in order to engage in successful cross-border dealings. Third, Kedia and Mukherji (1999) highlight the importance of a third facet, namely the information systems networks facilitated by the information and technological revolution (knowledge 3). Knowledge of information systems for data storage and retrieval, communication channels and networks and primacy of technology in the functioning of the organization are important avenues that managers operating in a boundaryless economy must possess (Helpman \& Rangel, 1999, Gunasekaran, et al. 2003).

Knowledge and information at the managerial level has been identified as being related to the global mindset of managers (Rhinesmith, 1993; Kedia \& Mukherji, 1999). Possession of a deeper level of knowledge and information at the managerial level enables managers to be able to comprehend the complexity in the economic, socio-cultural, political and technologically dynamic global environment. Furthermore, knowledge and information literacy about global contexts engenders a global perspective, and a global outlook (Jeanett, 2000). These arguments provide underpinning for three hypotheses:

H1. Knowledge 1 will positively influence global mindset.

H2. Knowledge 2 will positively influence global mindset.

H3. Knowledge 3 will positively influence global mindset.

\section{Skills and Abilities}

Skills are the essential competencies to put knowledge into practice. Prahalad and Cowin (1983) and Cheney et al. (1990) contend that the application of knowledge to periodically reorganize structures, rethink strategies, revamp systems in place and revise policies at the organizational level is vital to ensure long-term survival of organizations engaged in global business. How managers apply knowledge within organizations has been the subject of speculation and debate. One school of thought suggests that along with the possession of knowledge and information, managers need appropriate skill-sets to use and apply the acquired knowledge and information effectively and efficiently (Ali \& Horne, 1986; Rhinesmith, 1992; 1993; 1995; Kedia \& Mukherji, 1999; Athanasaw, 2003). In this context, Adler (1983) has identified some of the essential skills and abilities managers need to possess in order to work successfully in cross-cultural global environments. The current study herein explores 
three categories of skills and abilities identified by Adler (1983); namely professional and managerial skills which include skills managers need to possess while working in both a domestic and multinational environment; personal and social skills which allow managers the ability to manage their relationships with people from different contexts successfully; and, cross-cultural and international skills that are particularly important for managers working in geographically dispersed multicultural environments.

Kedia and Mukherji (1999) have developed a theoretical model linking skills and abilities of managers with their global mindset orientations. They argue that dynamic and competitive environments require micro level reform in terms of diversified managerial skills and abilities, which gives managers the necessary competencies to function effectively in the international environment. Stumpf (1989) and Rhinesmith (1993) have argued that managers who are exposed to the multinational environment are able to continually upgrade their skill-sets, and in turn their global mindset. These arguments support the postulation of the next three hypotheses.

H4. Professional and managerial skills will positively influence global mindset.

H5. Personal and social skills will positively influence global mindset.

H6. Cross-cultural and international skills will positively influence global mindset.

\section{Risk Tolerance}

Globalization entails high levels of risk (Clark \& Knowles, 2003; Ricks, 2003). Cross-border business dealings are risky given the uncertainty in the political, economic, socio-cultural, and technological environments in which organizations operate. In this regard, it has become imperative for managers operating in a competitive global marketplace to make decisions in the shortest possible time frame in order to gain maximum economic advantage. Such decisions entail a level of risk (business risk, political risk, social risk, economic risk, exchange risk, interest rate risk, and credit risk) which managers have to take into account while making those decisions. Several studies have explored the relationship of risk tolerance and globalization (Kedia \& Chhokar, 1986; Sullivan \& Bauerschmidt, 1990; Ali \& Swiercz, 1991). The findings indicate that managers working in multinational companies operating across national borders perceive risk taking as an entrepreneurial opportunity.

Diversifying into international markets is more often a strategic decision by organizations depending on, among other factors, the availability of resources 
(Robbins, et al. 2003) and the managerial perception of risk (Roth, 1992). This cognitive involvement in terms of managerial perception relates to their global mindset, i.e., their ability and willingness to perceive global expansion as opportunities rather than threats (Harveston, at al. 1999; Williams \& Voon, 1999). Roth (1992) contends that this perception of treating riskiness in international business dealings as opportunities requires a mindset orientation that appreciates globality. Building on existing theory in the international management area, the following hypothesis is presented.

H7. Risk tolerance will positively influence global mindset.

\section{Global Identity}

Managers working in multinational organizations are perceived to possess a global identity, giving them a psychological advantage over managers working in local organizations (Beechler, et al. 1999). Global identity, in turn 'encourages managers to think about the firm as a whole and to ignore cultural and other boundaries as appropriate' (Beechler, et al. 1999: 13). Researchers (Porter, 1986; Bartlett \& Ghoshal, 1998; Beechler \& Bltazley, 2008) contend that managers involved in cross-border dealings would have a better idea of structures, processes, systems and policies involved in international activities than a manager working in a small local organization.

A number of theories have linked global identity with global mindset (Ziller, 1973; Cox, 1994; Beechler, et al. 1999). Beecher, et al. (1999: 14) explain that '...the cognitive complexity and learning orientation of global mindset make it possible for managers to grasp the difficult, diverse, high entangled dispersed operations of the firm, and to understand the highly differentiated cultural, political, economic and market conditions in which both affiliates and individuals of the firm operate.' In addition, leading researchers contend that the ability and willingness of managers to think, act and transcend boundaries of values and goals on a global scale requires a global identity and thinking (Kanter, 1994; Bartlett \& Ghoshal, 1998; Bouquet, 2005). These contentions provide support for Hypotheses H8.

H8. Global identity will positively influence global mindset.

\section{Boundary Spanning Activities}

Boundary spanning activities have been defined as interactions exposing individuals and organizations to information and social environments, thereby affecting managerial views and strategic behavior of organizations (Beechler, et al. 
1999). The significance of individual boundary spanning activities has been recognized in diverse theoretical and empirical literature including new institutionalism (Powell \& DiMaggio, 1991), inter-organizational relationships and strategic alliances (Oliver, 1990), and managerial elites (Pettigrew, 1992). These initiatives have been reported to be enabled by increased managerial participation in boundary spanning activities. Some of these initiatives include international strategic alliances, joint ventures, international mergers and acquisitions, international supplier agreements, global responsibility designations, global team participation, ad hoc project groups, networks, and shared tasks or jobs across national boundaries (Adler \& Bartholomew, 1992; Pucik, 1992).

Beechler, et al. (1999) have reported the relationship between boundary spanning activities and global mindset. The authors contend that boundary spanning activities are structured opportunities to foster global mindset development. Two empirical studies by Calori et al. (1994) and Kobrin (1994) provide evidence that boundary spanning activities help shape the cognitive structures and processes of individuals, by providing access to diverse sources of cultural, economic and socio-political information, i.e., the global mindset orientations of managers. Murtha, Lenway and Bagozzi (1998), and Kanter (1991) also provide empirical evidence on the linkage between boundary spanning activities and their shaping global mindset orientations. The current study tests the importance of boundary spanning activities on the managers' global mindset. Based on this evidence, hypothesis H9 is formulated.

H9. Boundary spanning activities (importance) will positively influence global mindset.

\section{Level of International Experience}

A number of studies have reported the relationship between managerial international experience and globalization of business activities (Bilkey, 1978; Tung $\&$ Miller, 1990). These studies contend that managers are likely to develop a deeper level of understanding of the context in which their organization operates when they have first-hand experience of living, working and liaising with their business counterparts overseas. In addition, it is expected that managers with international degrees and qualifications would have superior knowledge of the foreign market conditions than managers with a local education (Harveston, et al. 1999).

The level of international experience also influences the level of global mindset (Bloodgood et al. 1997). Researchers contend that knowledge of and exposure to different work practices, policies and procedures in foreign locations provides 
managers with superior ability to work in a global context by providing a cognitive mind frame that is more receptive to globality (Jeanett, 2000; Bouquet, 2005). Furthermore, senior managers with greater exposure to international activities and a higher level of international experience are generally more adept at thinking and acting globally, and hence are in possession of a mindset orientation attuned to the dynamic international environment (Hambrick \& Phyllis, 1984; Bantel \& Jackson, 1989). Embedded in this knowledge, hypothesis H10 is established.

H10. Level of international experience will positively influence global mindset.

\section{METHODOLOGY}

\section{Research Design}

The study employed a mixed method research design. Increasingly, scholars (Adler, Campbell \& Laurent, 1989; Teagarden, et al. 1995; Offermann \& Spiros, 2001; Denscombe, 2008) are applying both quantitative and qualitative, or mixed method approaches to their investigations. The main reason why such an approach is gaining currency is the recognition of the need to complement quantitative with qualitative techniques to provide researchers with a deeper understanding of the pattern of statistical results (De Ruyter et al., 2001; Trevelyan, 2001; Bryman, 2006; Tashakkori \& Teddlie, 2009). According to Morse and Niehaus (2009), a mixed method should include a core component and supplementary component, the choice of which is determined by the theoretical drive of the project. In this research herein, the theoretical drive is quantitative with the core component being a survey and the supplementary component being qualitative feedback sessions in the form of in-depth structured interviews and focus group sessions. The survey instrument was administered in English in India, in Mandarin in China, and in Japanese in Japan. The English version of the questionnaire was translated into Mandarin and Japanese by professional translators. They were back translated into English by another set of translators. The qualitative feedback sessions were conducted in English in India, in Mandarin in China, and in Japanese in Japan. Professional translators assisted the translation of the Chinese and Japanese feedback sessions into English.

\section{Site and Sample}

Organizations with a significant global presence were selected for the research. In all three countries, namely India, China, and Japan, service sector organizations were surveyed. A total of 695 questionnaires were distributed to managers at various 
levels in the organizations of which 265 were in India, 230 in China, and 200 in Japan. Responses rates were $90 \%$ for India and China, and 35\% for Japan. The sample was then composed of 239 from India, 210 from China, and 55 from Japan, providing a total of 504.

Table 1 Demographics

\begin{tabular}{|c|c|c|c|c|c|c|c|}
\hline & $\begin{array}{c}\text { India } \\
(n=239)\end{array}$ & $\begin{array}{l}\text { China } \\
(n=210)\end{array}$ & $\begin{array}{l}\text { Japan } \\
(\mathrm{n}=55)\end{array}$ & & $\begin{array}{c}\text { India } \\
(n=239)\end{array}$ & $\begin{array}{c}\text { China } \\
(n=210)\end{array}$ & $\begin{array}{l}\text { Japan } \\
(n=55)\end{array}$ \\
\hline $\begin{array}{l}\text { Managerial } \\
\text { Level }\end{array}$ & & & & Gender & & & \\
\hline Executive & 35.1 & 28.6 & 69.1 & Female & 33.5 & 38.6 & 3.6 \\
\hline Middle & 40.6 & 45.2 & 20.0 & Male & 66.5 & 61.4 & 96.4 \\
\hline Supervisory & 24.3 & 26.2 & 10.9 & & & & \\
\hline Age (years) & & & & Tenure (years) & & & \\
\hline$<30$ & 24.6 & 29.5 & 1.8 & $<10$ & 34.7 & 61.9 & 12.7 \\
\hline $30-39$ & 37.7 & 46.7 & 7.3 & $10-19$ & 51.1 & 28.1 & 20.0 \\
\hline $40-49$ & 28.9 & 21.0 & 30.9 & 20 and above & 14.2 & 10.0 & 67.3 \\
\hline 50 and above & 8.8 & 2.8 & 60.0 & & & & \\
\hline $\begin{array}{l}\text { Educational } \\
\text { Background }\end{array}$ & & & & $\begin{array}{l}\text { International } \\
\text { Dimension in } \\
\text { Education }\end{array}$ & & & \\
\hline University & 83.3 & 92.9 & 92.7 & & 15.1 & 63.8 & 65.5 \\
\hline
\end{tabular}

Note: Total $(\mathrm{n}=504)$

A prominent feature of the sample was that one third of the managers represented were female in India and China, compared to less than $4 \%$ female representation in the Japanese sample. This feature demonstrated the changing role of women in the corporate scenario in the two traditionally male-dominated societies of India and China, and the strong male-oriented corporate scenario in Japan. A second feature was the dominance of younger managers ( $<40$ years of age) represented by $62.4 \%$ in India, and $76.2 \%$ in China, respectively. This feature was characteristic of the importance placed on a young well-trained and skilled workforce, coupled with the phasing out of the seniority-based promotion system in both countries. This was not the case with the Japanese sample with only $9.1 \%$ of managers being under 40 years old. A third feature of the sample was respondents reporting extensive work experience, which is illustrated by $65.3 \%$ of Indian managers, $38.1 \%$ of the Chinese managers, and $87.3 \%$ of the Japanese managers having more than 10 years experience. A final notable 
feature of the sample was the importance placed on university education, with over $83 \%$ of the managers possessing university degrees in the three countries (Table 1).

The supplementary qualitative component consisted of in-depth structured interviews, and focus group sessions in India (15 participants in face-to-face interviews), China (15 participants with five face-to-face interviews, and two focus groups of five managers each), and Japan (6 participants with three face-to-face interviews, and one focus group of three managers) in which the results of the quantitative analysis were discussed. The participants were selected to reflect the quantitative sample. Participants were presented with the quantitative results and asked questions about how well these results reflected their experiences and perceptions. The Indian and Chinese interviews were recorded and transcribed verbatim. The Japanese participants did not consent to the sessions being recorded, and hence their comments were transcribed verbatim at the respective sessions. Using a qualitative analysis software package (NVivo v.8), content analysis was conducted to identify themes that were then compared and contrasted with quantitative findings, in order to triangulate and further dimensionalize the results. Lindsay (2004, p. 488) observed that the NVivo software can provide 'more rigor and traceability' than manual coding, and is useful for identifying emerging categories and themes.

\section{Measures, Factor analyses and Reliabilities}

\section{- Knowledge and Information}

In the absence of an instrument, knowledge and information was measured using an instrument developed by this study from underpinning theory. Three items were developed to measure each of the three dimensions of knowledge and information (namely knowledge 1, 2 and 3) from existing literature based on Rhinesmith (1992; 1993; 1995) and Kedia and Mukherji (1999). The items were pilot tested with 50 Indian and Chinese managers, and exploratory factor analyses (EFA) revealed robust results and hence the items retained for the study. Responses were given on a seven-point Likert scale to indicate the level of importance each item had with respect to working in the global marketplace. EFA revealed three constructs. However one item measuring Knowledge 2 was deleted as the item cross-loaded. The Cronbach's alpha reliabilities for the three constructs were $0.78,0.75$, and 0.78 , respectively.

\section{- Skills and Abilities}

Skills and Abilities were measured using an adapted version of a scale initially developed by Adler (1983), and shortened from 27 to 16 statements by Ali and Horne 
(1986). Two further items were deleted for vocabulary equivalence. The scale measures three sub-dimensions of the necessary attributes, namely, professional and managerial skills (four items), personal and social skills (seven items), and cross-cultural and international skills (three items). Respondents reported their perceptions on the level of importance of the skills and abilities for global business on a seven-point Likert scale. The EFA revealed some cross-loading and these items were deleted. The final factor structure revealed three factors cross-cultural and international skills, personal and social skills, and professional and managerial skills with cronbach alphas of $0.81,0.73$, and 0.71 , respectively.

\section{- Risk Tolerance}

Risk tolerance was measured using a scale developed by Covin and Slevin (1989) and later adapted by Roth (1992) and then by Harveston, et al. (1999) in their seminal work on the internationalization of born global and gradual globalizing firms. The variable was assessed by five questions dealing with the global activities. Respondents were asked to respond on a seven-point Likert scale. The EFA confirmed the unidimensionality of the construct with a reliability measure of 0.76 .

\section{- Boundary Spanning Activities}

In the absence of a readily available instrument, a ten-item scale was developed from Murtha, Lenway and Bagozzi (1998). Respondents were asked to respond on a seven-point Likert scale to indicate the level of importance each activity had, with respect to working in the global marketplace. Murtha, Lenway and Bagozzi (1998) reported that boundary spanning activities are comprised of independent, mutually exclusive activities enabling convergence of cross-border informational boundaries. The items were pilot tested with 50 Indian and Chinese managers, and the unidimensionality confirmed in the EFA. In the final analysis, the EFA revealed a single factor as well with a Cronbach's alpha score of 0.84 .

\section{- Global Identity}

In the absence of a readily available instrument measuring global identity, a new instrument was developed based on the work of Hodgetts and Luthans (1994) and Perlmutter (1969) who referred to global identity as providing global managers with a psychological advantage, due to their exposure to global activities. An eight-item scale was developed to measure global identity. The scale was pilot tested with a sample of 50 Indian and Chinese managers, and the findings suggested that the items 
were robust. Respondents were asked to report on a seven-point Likert scale to indicate the level of importance each action had in working in the global marketplace. Based on the EFA, one item cross-loaded and was subsequently deleted. The Cronbach's alpha score for this construct was 0.82 .

\section{- Level of International Experience}

This was measured using an instrument developed by Harveston (2000) which was adapted from Harveston, et al. (1999). Level of international experience was assessed by four questions about the respondents work, travel, education and vacation ativities in an international context. Respondents were asked to respond on a seven-point Likert scale to indicate their level of involvement with each activity. The EFA resulted in a single factor with an alpha of 0.90 .

\section{- Global Mindset}

Following the work of Barham (1987), Cateora (1993), Gray (1997), and Kedia and Chhokar (1986), global mindset was assessed by asking managers a series of questions about their attitudes towards globalization. Questions were adapted from Burpitt and Rondinelli (1998). Respondents were asked to report on a seven-point Likert scale to indicate their level of agreement with each statement. All four items loaded onto one factor with an alpha of 0.84 .

Harman's single factor test was conducted with the items retained after the EFA, and these were tested for common method variance. In line with Podsakoff et al. (2003), the items were subject to an un-rotated factor analysis which resulted in multiple factors with eigenvalues greater than 1.0, which suggested that the measures were distinct, thus minimizing concerns about common method bias (Chen, Aryee \& Lee, 2005).

\section{Quantitative Findings}

\section{RESULTS}

The quantitative data was analyzed using stepwise multiple regression analysis to test the effects of the independent variables (H1-H10) as well as the control variables (country, gender, age, managerial level, and education background) on global mindset. All the control variables were non-significant. The results are presented in Table 2.

Four of the ten hypotheses were supported by the multiple regression analysis (Table 2), namely H1, H7, H9 and H10, with no significant variances across India, China, and Japan. From these results, two main conclusions can be drawn. First, only 
four of the ten skill-sets had a statistically significant connection to the global mindset. Second, lack of variation across the three contexts suggested that there were no cultural factors at play in the sample. The qualitative analysis provides a first-hand interpretation and validation of the quantitative findings and is presented in the next section.

Table 2 Multiple Regression Analysis Results

\begin{tabular}{cccccc}
\hline Hypothesis & Path from & To & Beta & $\mathrm{t}$ & Sig \\
\hline H1 & Knowledge1 & Gmindset & 0.080 & 2.075 & $0.039^{*}$ \\
\hline H2 & Knowledge2 & Gmindset & 0.063 & 1.435 & 0.152 \\
\hline H3 & Knowledge3 & Gmindset & 0.077 & 1.956 & 0.510 \\
\hline H4 & Skill1 & Gmindset & -0.023 & -0.453 & 0.651 \\
\hline H5 & Skill2 & Gmindset & 0.046 & 1.106 & 0.269 \\
\hline H6 & Skill3 & Gmindset & 0.001 & 0.012 & 0.990 \\
\hline H7 & Risktolerance & Gmindset & 0.445 & 9.613 & $0.000^{* *}$ \\
\hline H8 & Globaliden & Gmindset & 0.056 & 1.070 & 0.285 \\
\hline H9 & Boundaryimp & Gmindset & 0.268 & 4.910 & $0.000^{* *}$ \\
\hline H10 & Intexperience & Gmindset & 0.052 & 2.199 & $0.028^{*}$ \\
\hline
\end{tabular}

F: 29.598; Adjusted $R^{2}: 0.460$

Notes: 1 . Knowledge1 = knowledge of information systems networks facilitated by the information and technological revolution; Knowledge2 = knowledge of socio-political differences across countries and regions; Knowledge 3 = organizational and societal culture and cross cultural issues that impact management; Skill1 = professional and managerial skills; Skill2 = personal and social skills; Skill3 $=$ cross cultural and international skills; Risktolerance $=$ risk tolerance; Globaliden = global identity; Boundaryimp = boundary spanning activities importance; Intexperience $=$ level of international experience; Gmindset = global mindset .

2. $\mathrm{p}^{*}<0.05 ; \mathrm{p}^{* *}<0.001$.

\section{Qualitative Findings}

- H1 - Knowledge of information systems networks facilitated by the information and technological revolution

This skillset had a significant contribution toward global mindset intensity. Interview participants from the Indian sample explained its importance. For example, an Indian manager employed with a multinational bank stated that,

'...The basic laptop, access to internet etc. is given to all managers these days. Managers and staff are adequately trained to handle systems commensurate with their job profiles'. (Interview India 1) 
To add to this, a senior manager with a large IT multinational company in India explained the importance of knowledge in relation to information technology, and basic computer related IT skills that assist in creating a managerial global mindset. This manager stated that,

'...Definitely the key thing is communicating. Communication across locations, geographies, nations, regions, and cultures is by far the single most tough thing...given all competencies as equal, the guy who can communicate better across regions comes out first. The manager has to be technology savvy... and be informed of trends, changes, not just in the local context, but also in the international global context'. (Interview India 2)

Participants in the Chinese sample also explained the importance of information technology. The Director of a Chinese IT organization explained that,

'The Influence of technology [on our sector] is huge...have to provide value added service through the use of technology...'. (Focus Group China 1)

Similarly Japanese managers also agreed that it was impossible to keep away from technology and hence managers needed to constantly upgrade their IT and communication knowledge base. A senior manager from a Japanese higher education sector explained,

'In a globally advanced economy like Japan, it is vital for managers to update their information skills which they use for communication constantly. Everything is online these days' (Interview Japan 2)

It seems then that for the three samples, connectivity and communication are key elements. This connects closely with the growing importance of instantaneous real-time global communications' (Held \& McGrew, 2007, p.4) and the value of global knowledge flows, as opposed to the flow of goods.

\section{- H7 - Risk Tolerance}

The quantitative results suggest that risk tolerance was considered important across the sample. The qualitative data suggests that there was a perception that global managers need a higher threshold of dealing with risk when operating in the complex global environment. This emphasized the need to look beyond extant risks and develop a mindset with a high risk tolerance level. For those participants from Indian and Chinese organizations, this risk was engaged by employing risk managers who 
were specialists in forecasting and mitigating risk in a global context. A manager employed by a leading Indian remittance gateway organization explained that these risk managers,

'...Had a thorough understanding of the organization's business, and were in charge of developing plans, policies and measures that assisted dealing with various types of crises. (Interview India 3)

The Japanese participants tended to recognize and accept that doing effective business on the global stage requires acceptance of risk. This was highlighted by the General Manager of a leading Japanese Oil and Gas Exploration Service Company who explained that,

'...Doing business overseas is risky. It is important for the global manager to understand risk and deal with it'. (Interview Japan 3)

This contrast is significant in that globalization can be equated with the emergence of a 'risk society' (Beck, 2000; 2002) in which risk is an ever-present and transformative influence. It seems that the Japanese participants are adapting to the challenges posed by this through direct engagement, and the Chinese and Indian participants have yet to fully come to terms with risk, preferring their engagement to be mediated trough a third party 'expert'.

\section{- H9 - Boundary Spanning Activities}

At the organizational level, the quantitative findings suggest that boundary spanning activities are important contributors to the cultivation of a global mindset in the sample. For participants in India and China, such cross-border liaisons (organization to organization) were instrumental in the development and nurturing of their global mindset orientations, as the liaisons provided managers with an understanding and appreciation of the ever-increasing possibilities in the globalized business marketplace.

An Indian manager with an MNC bank explained the role of boundary spanning activities that led to the development of a global mindset. He stated that

'... Being involved in global strategy development, cross-border projects and tasks and overseas postings are vital to get a feel for how global business works, and this in a sense is what enables us to think globally - it's the attitude that 'we are global' that is important'. (Interview India 5) 
The Japanese managers also explained the link between boundary spanning activities and global mindset orientations. For example, a senior manager of a Japanese mining services organization explained that

'...In our industry, the service we provide in other countries is based on our knowledge and technical expertise. We regularly send staff overseas to participate in cross-border activities and this is invaluable as it helps develop their mindset' (Focus group Japan 4)

These perceptions reflect the intensification of interconnectedness of institutions and organizations being brought about by globalization (Held \& McGrew, 2007).

\section{- H10 - Level of International Experience}

Managers from India and China were clear about the importance of international experience towards global mindset orientation. There was a consensus among the Indian and Chinese managers who explained that 'spending time overseas' and 'experiencing foreign customs, traditions and cultures' was important in shaping the global mindset. This in turn allowed managers to develop tolerance towards differences across geographic boundaries and ultimately develop a global mindset as explained by a senior Indian manager employed by a global Online Remittance organization.

'... Appreciate globalization as being favourable not just for themselves but for the organizations that they represent'. (Interview India 3)

The General Manager of a leading Japanese shipping service organization explained,

'Experience is everything in our industry. You cannot learn anything about international affairs, how to do business overseas and other aspects without international experience. Experience is more important for mindset development than just knowledge.' (Interview Japan 1)

In summary, the qualitative analysis supports and expands upon the results of the quantitative analysis. The main finding of the qualitative analysis is that it validates and explains the quantitative results. While the hypothetical model is broadly supported in this analysis, the results suggest that there is a set of primary global mindset antecedents that are significant across the three countries. While there was convergence in the antecedents that led to the development of the managers' global 
mindsets in the three countries, the qualitative comments suggested some difference in interpretation of the significant findings. Giddens' (2002) notion of globalization as an 'in-here/out there' phenomenon is useful on this point. It seems that for those in the Indian and Chinese sample, the foundation of the global mindset is that globalization is an 'out there' first and 'in here' second. They see the global mindset as primarily being defined by their organization for them to adopt. In contrast, those in the Japanese sample appear to have taken the stance that the global mindset as being primarily grounded in globalization as an 'in here' phenomenon' first, and 'out there' second. In other words for them, a global mindset is more defined by the individual rather than the organization.

\section{DISCUSSION AND CONCLUSION}

This research is confined to the three nations of India, China, and Japan, and more research is required in other cultural contexts to further explore the effects of cultural nuances, if any, on global mindsets. On the one hand, this analysis confirms much of the literature on global mindsets, particularly the influence of its antecedents and the assertion by Levy, et al. (2007) that an integrated approach to analysis should be adopted. Significantly though, the analysis does suggest that the executives in China, India, and Japan are adopting hybridized perspectives on business and globalization. McKenna (2011) calls for more research into the business perspectives in such nations. We have found that for business people in India and China, there are variations in how they interpret their environments. They have a 'global mindset' but there are nuanced differences. This has implications for theory in that it is necessary to account for 'increasingly hybridized, multipolar economic world wherein China and India are likely to be critical and very powerful centres' (McKenna, 2011, p. 403).

From a methodological point of view, this analysis has demonstrated the usefulness of adopting a mixed method approach. It has proven to be very useful in not only examining global mindsets using valid and rigorous measurement scales, but also in providing subtle insights into the phenomenon that only qualitative analysis can provide. In effect, this research employed the strengths of both approaches to tackle the research problem.

The practical implications of this research are also significant. The results have illuminated a convergence in the antecedents that led to the development and shaping of the managers global mindsets across the three countries. Cultural differences were not as significant as one might expect. While this could be attributable to the nature of the sample, for Indian, Chinese, and Japanese organizations engaged in international 
business, the Human resource (HR) departments of these organizations have a challenge in understanding the emerging hybridized global mindset orientation among its managers across different organizational levels. Developing new (non-Western-based) HR training in particular to foster the significantly reported skill-sets could be critical for Indian, Chinese, and Japanese organizations. These organizations would require self-motivated individuals who would possess or develop the assessed individual level skill-sets that contribute towards their global mindset orientations. Notwithstanding the role of HR departments in global organizations in the three countries, it is envisaged that certain organizational level reform measures specifically targeted at the identification, development and maintenance of high levels of global mindset orientation is vital for continued global success. These contentions support the existing literature on the need for intelligent global organizations to possess managers with a global mindset (Murtha, Lenway \& Bagozzi 1998; Beechler, et al. 1999; Jeanett, 2000; Gupta \& Govindarajan, 2002; Begley \& Boyd, 2003; Beechler \& Bltazley, 2008; Ananthram, Chatterjee \& Pearson, 2010).

Based on the converging patterns observed in this study, future researchers are encouraged to explore the impact of hybridized perspectives, and the associated antecedent skill-sets that constitute global mindsets in different Asian and non-Asian contexts. This analysis is important because although there is a general acceptance of the notion of 'global mindset' the exact hows and whys seem to be a matter of cultural interpretation. Researchers are also encouraged to examine the differences across industry sectors with larger samples as well as across organizations at different stages of the globalization process.

\section{REFERENCES}

Adler, N. J. (1983). Cross-cultural management issues to be faced. International Studies of Management and Organization, 13(1-2), 7-45.

Adler, N. J. \& Bartholomew, S. (1992). Managing globally competent people. The Academy of Management Executive, 6(3), 52-65.

Adler, N. J., Campbell, N., \& Laurent, A. (1989). In search of the appropriate methodology: Outside the People's Republic of China looking in. Journal of International Business Studies, 20(1), 61-74.

Ali, A. \& Horne, D. (1986). Problems and skills in international business. Management Memo, 1(May), 34-38.

Ali, A. \& Swiercz, P. M. (1991). Firm size and export behavior: Lessons from the Midwest. Journal of Small Business Management, 29(2), 71-78. 
Ananthram, S., Pearson, C. A. L. \& Chatterjee, S. R. (2010). Do organisational reform measures impact on global mindset intensity of managers? Empirical evidence from Indian and Chinese service industry managers. Journal of Chinese Economic and Foreign Trade Studies, 3(2), 146-168.

Athanasaw, Y. A. (2003). Team characteristics and team member knowledge, skills, and ability relationships to the effectiveness of cross-functional teams in the public sector. International Journal of Public Administration, 26(10-11), 1167-1179.

Baines, A. (1998). Using information technology to facilitate organizational change. Work Study, 47(2), 49-55.

Bantel, K. A. \& Jackson, S. E. (1989). Top management and innovations in banking: Does the composition of the team make a difference? Strategic Management Journal, 10(2), 107-124.

Barham, K. (1987). The internationalisation of business and the international manager. Industrial and Commercial Training, 19(4), 6-11.

Bartlett, C. \& Ghoshal, S. (1998). Managing across borders. (2nd ed.). Cambridge, MA: Harvard Business School Press.

Beck, U. (2000). What is globalization? Cambridge: Polity.

Beck, U. (2002). The terrorist threat: World risk society revisited. Theory, Culture and Society, 19(4), 39-55.

Beechler, S., \& Baltzley, D. (2008). Creating a global mindset. Chief Learning Officer, 7(6), 40-45.

Beechler, S., Taylor, S., Boyacigiller, N. A., \& Levy, O. (1999, August). Building global mindset for competitive advantage: A conceptual integration of global mindset, international human resource management, and organizational performance in multinational corporation. Paper presented at the Annual Meeting of the Academy of Management, Chicago, IL.

Begley, T. M. \& Boyd, D. P. (2003). The need for a corporate global mind-set. MIT Sloan Management Review, 44(2), 25-32.

Bilkey, W. J. (1978). An attempted integration of the literature on the export behavior of firms. Journal of International Business Studies, 9(1), 33-46.

Bloodgood, J. M., Sapienza, H. J. \& Almeida, J. G. (1997). The internationalization of new high-potential U.S. ventures: Antecedents and outcomes. Entrepreneurship, Theory and Practice, 20(4), 61-76.

Bouquet, C. (2005). Building global mindsets: An attention-based perspective. UK: Palgrave Macmillan. 
Bowen, D. E. \& Inkpen, A. C. (2009). Exploring the idea of "Global Mindset" in leading change in international contexts. Journal of Applied Behavioural Science, 45(2), 239-260.

Bryman, A. (2006). Integrating quantitative and qualitative research: how is it done? Qualitative Research, 6(1), 97-113.

Burpitt, W. J. \& Rondinelli, D. A. (1998). Export decision-making in small firms. The Role of Organizational Learning, 33(1), 51-68.

Calori, R., Johnson, G., \& Sarnin, P. (1994). CEO's cognitive maps and the scope of the organization. Strategic Management Journal, 15(6), 437 - 457.

Cateora, P. (1993). International marketing. (9th ed.). Chicago, IL: Irwin.

Chen, Z. X., Aryee, S., \& Lee, C. (2005). Test of a mediation model of perceived organizational support. Journal of Vocational Behavior, 66(3), 457-470.

Cheney, P. H., Hale, D. P., \& Kasper, G. M. (1990). Knowledge, skills and abilities of information systems professionals: Past, present and future. Information and Management, 19(4), 237-247.

Clark, T. \& Knowles, L. L. (2003). Global myopia: Globalization theory in international business. Journal of International Management, 9(4), 361-372.

Cohen, S. L. (2010). Effective global leadership requires a global mindset. Industrial and Commercial Training, 42(1), 3-10.

Covin, J. \& Slevin, D. (1989). Strategic management of small firms in hostile and benign environments. Strategic Management Journal, 10(1), 75-87.

Cox, T. H. (1994). Cultural diversity in organizations. San Francisco: Berrett-Koehler.

Das, D. K. (2006). China and India: A tale of two economies. London: Routledge.

De Ruyter, K., Moorman, L., \& Lemmink, J. (2001). Antecedents of commitment and trust in customer-supplier relationships in high technology markets. Industrial Marketing Management, 30(3), 271-286.

Denscombe, M. (2008). Communities of practice: A research paradigm for the mixed methods approach. Journal of Mixed Methods Research, 2(3), 270-283.

Fatehi, K. (1996). International management: A cross-cultural and functional perspective. Upper River Saddle, NJ: Prentice-Hall.

Giddens, A. (2002). Runaway world: How globalization is reshaping our lives. London: Profile Books.

Gray, B. J. (1997). Profiling managers to improve export promotion targeting. Journal of International Business Studies, 28(2), 387-421. 
Gunasekaran, A., Khalil, O. E. M., \& Rahman, S. M. (Eds.). (2003). Knowledge and information management: Human and social perspective. Hershey, PA: Idea-Group Publishing.

Gupta, A. K. \& Govindarajan, V. (2002). Cultivating a global mindset. Academy of Management Executive, 16(1), 116-126.

Hambrick, D. C. \& Phyllis, A. M. (1984). Upper echelons: The organization as a reflection of its top managers. Academy of Management Research, 9(2), 193-206.

Harveston, P. D. (2000). Synoptic versus incremental internationalization: An examination of "Born Global" and "Gradual Globalizing" firms. Unpublished Doctoral Dissertation, University of Memphis, USA.

Harveston, P. D., Kedia, B. L., \& Davis, P. S. (1999). Internationalization of born global and gradual globalizing firms: The impact of the manager. Journal of Global Competitiveness, 7(1), 278-286.

Held, D. \& McGrew, A. (2007). Globalizatio/anti-globalization: Beyond the great divide. (2nd ed.). Cambridge: Polity.

Helpman, E. \& Rangel, A. (1999). Adjusting to a new technology: Experience and training. Journal of Economic Growth, 4(4), 359-380.

Hodgetts, R. M. \& Luthans, F. (1994). International management. New York, NY: McGraw-Hill.

Hofstede, G. (1991). Cultures and organizations: Software of the mind. London: McGraw-Hill.

Ikenberry, G. J. (2008). The rise of China and the future of the West (cover story). Foreign Affairs, 87(1), 23-31.

Jeanett, J. P. (2000). Managing with a global mindset. Great Britain: Pearson Education Limited.

Kanter, R. M. (1991). Transcending business boundaries: 12,000 world managers view change. Harvard Business Review, 69(3), 151-164.

Kanter, R. M. (1994). Afterword: What 'Thinking Globally' really means. In R. S. Barnwik \& R. M. Kanter (Eds.), Global strategies (pp. 227-232). Boston: Harvard Business School Press.

Kedia, B. \& Chokkar, J. (1986). Factors inhibiting export performance of Firms: An empirical investigation. Management International Review, 26(4), 33-43.

Kedia, B. L. \& Mukherji, A. (1999). Global managers: Developing a mindset for global competitiveness. Journal of World Business, 34(3), 230-251. 
Kobrin, S. J. (1994). Is there a relationship between a geocentric mind-set and multinational strategy? Journal of International Business Studies, 25(3), 493-511.

Levy, O., Taylor, S., Boyacigiller, N. A., \& Beechler, S. (2007). Global mindset: a review and proposed extensions. Advances in International Management, 19, $11-47$.

Lindsay, V. (2004). Computer-assisted qualitative data analysis: Application in an export study. In R. Marschan-Piekkari and C. Welch (Eds.), Handbook of Qualitative Research Methods for International Business (pp. 486-506). Cheltenham: Edward Elgar.

McKenna, S. (2011). A critical analysis of North American business leaders' neocolonial discourse: global fears and local consequences. Organisation, 18(3), 387-406.

Miller, R. and Wurzburg, G. (1995). Investing in human capital. The OECD Observer, 193, 16-19.

Morse, J. M, \& Niehaus, L. (2009). Mixed method design: Principles and procedures. Walnut Creek: Left Coast Press.

Murtha, T. P., Lenway, S. A., \& Bagozzi, R. P. (1998). Global mind-sets and cognitive shift in a complex multinational corporation. Strategic Management Journal, 19(2), 97-114.

Naik, J. \& Iyengar, G. (2003). Knowledge management process framework. In R. Lee (Ed.), Knowledge management: Principles and applications (pp. 83-100). Singapore: Singapore Institute of Materials Management.

Offermann, L. R. \& Spiros, R. K. (2001). The science and practice of team development: Improving the link. Academy of Management Journal, 44(2), 376-392.

Oliver, C. (1990). Determinants of inter-organizational relationship: Integration and future directions. Academy of Management Review, 15(2), 241-265.

Ortenblad, A. (2004). The learning organization: Towards an integrated model. The Learning Organization, 11(2), 129-144.

Parkan, B. (2009). On multinational corporations and the provision of positive rights. Journal of Business Ethics, 85(1-Supplement), 73-82.

Pekkanen, S. M. \& Tsai, K. S. (2005). Late liberalizers: Comparative perspectives on Japan and China. In S. M. Pekkanen and K. S. Tsai (Eds), Japan and China in the world political economy (pp. 11-28). London: Routledge. 
Pempel, T. J. (2005). Revisiting the Japanese economic model. In S. M. Pekkanen and K. S. Tsai (Eds.), Japan and China in the world political economy (pp. 29-44). London: Routledge.

Perlmutter, H. V. (1969). The tortuous evolution of the multinational corporation. Columbia Journal of World Business, (January-February), 9-18.

Pettigrew, A. M. (1992). On studying managerial Elites. Strategic Management Journal, 13(S2), 163-182.

Pies, I., Beckmann, M., \& Hielscher, S. (2010). Value creation, management competencies, and global corporate citizenship: An ordonomic approach to business ethics in the age of globalization. Journal of Business Ethics, 94(2), 265-278.

Podsakoff, P. M., MacKenzie, S. B., Lee, J. Y., \& Podsakoff, N. P. (2003). Common method biases in behavioral research: A critical review of the literature and recommended remedies. Journal of Applied Psychology, 88(5), 879-903.

Porter, M. E. (1986). Competition in global industries. Boston, MA: Harvard Business School Press.

Powell, W. W. \& DiMaggio, P. J. (1991). The new institutionalism in organizational analysis. Chicago: University of Chicago Press.

Prahalad, C. K. \& Cowin, R. M. (1983). Developing strategic capability: An agenda for top management. Human Resource Management, 22(3), 237-255.

Pucik, V. (1992). Globalization and human resource management. In V. Pucik, N. Tichy, and C. Barnett (Eds.), Globalizing management: Creating and leading the competitive organization (pp. 61-84). New York: John Wiley and Sons.

Ricks, D. A. (2003). Globalization and the role of the global corporation. Journal of International Management, 9(4), 355-359.

Rhinesmith, S. H. (1992). Global mindsets for global managers. Training and Development, 46(10), 63-69.

Rhinesmith, S. H. (1993). A manager's guide to globalization: Six keys to success in a changing world. New York: Irwin.

Rhinesmith, S. H. (1995). Open the door to a global mindset. Training and Development, 49(5), 35-43.

Robbins, S. P., Bergman, R., Stagg, I., \& Coulter, M. (2003). Foundations of Management. Frenchs Forest: Prentice Hall.

Rogers, E. M. \& Blonski, D. (2010). The global leadership mindset. Chief Learning Officer, 9(6), 18-21. 
Roth, K. (1992). Implementing international strategy at the business unit level: The role of managerial decision-making characteristics. Journal of Management, 18(4), 769-789.

Stumpf, S. A. (1989). Work experiences that stretch the manager's capacity for strategic thinking. Journal of Management Development, 8(5), 31-39.

Sullivan, D. \& Bauerschmidt, A. (1990). Incremental internationalization: A test of Johanson and Vahlne's thesis. Management International Review, 30(1), 19-30.

Tashakkori, A. \& Teddlie, C. (2009). Foundations of mixed methods research: Integrating quantitative and qualitative approaches in the social and behavioral sciences. Thousand Oaks: Sage Publications.

Teagarden, M. B., Von Glinow, M. A., Bowen, D. E., Frayne, C. A., Nason, S., Huo, Y. P., Milliman, J., Arias, M. E., Butler, M. C., Geringer, J. M., Kim, N., Scullion, H., Lowe, K. B., \& Drost, E. A. (1995). Toward a theory of comparative management research: An idiographic case study of the best international human resources management project. Academy of Management Journal, 38(5), 1261-1287.

Trevelyan, R. (2001). The paradox of autonomy: A case of academic research scientists. Human Relations, 54(4), 495-525.

Tung, R. L. \& Miller, E. W. (1990). Managing in the Twenty-First century: The need for global orientation. Management International Review, 30(1), 5-18.

Williams, S. \& Voon, Y. W. W. (1999). The effects of mood on managerial risk perceptions: Exploring affect and the dimensions of risk. The Journal of Social Psychology, 139(3), 268-287.

Ziller, R. C. (1973). The Social Self. New York: Pergamon Press. 
